\title{
THEORETICAL ANALYSIS OF DEVELOPED BRUSHLESS DC MOTOR
}

\author{
A. M. AL-Khatib*, W. Sh. Abou-Alfadl F. A. Abdel-kader*, and E. M. Badr ${ }^{* *}$ \\ *Department of Electrical Engineering, Faculty of Engineering, Minoufiya University, \\ Shebin El-Kom, Egypt \\ ***North Delta Electricity Distribution Company
}

\begin{abstract}
This paper presents a theoretical analysis of developed DC permanent magnet brushless motor. This motor has three phase cylindrical stator windings and two salient poles permanent magnet rotor. The motor construction, equivalent circuit, analysis and motor characteristics are given. The motor has a high value of the ripple factor. This problem may be overcome by improving the excitation method. The switching ON time of excitation for each phase can be advanced. The motor torque behavior is improved with increasing this advanced time (angle). The optimum angle is $40^{\circ}$ for phase advancing. The results show the increasing and continuity of the output torque with minimum ripple factor. This leads to increasing of the developed torque for the same motor dimensions.

هذا البحث يقدم التحليل النظري لمحرك التيار المستمر الافرشي المطور ذو المغناطيس الدائم ـ يتركب هذا المحرك

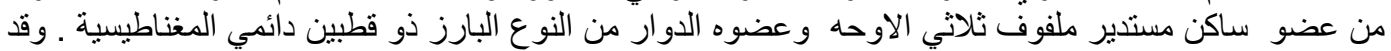

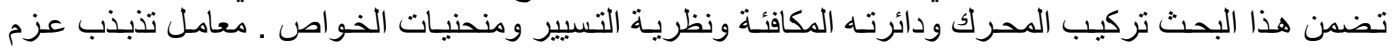

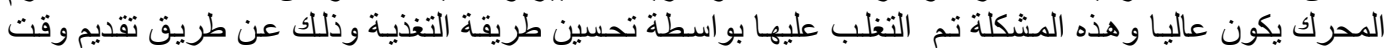

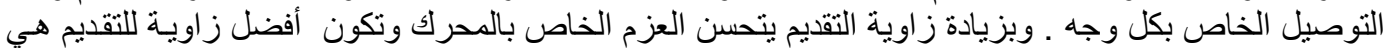

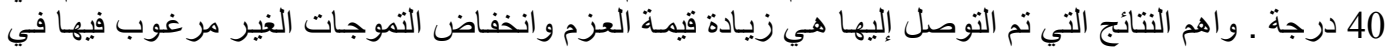
موجة العزم ـ و هذا يعني تحقيق الهدف بتطوير أداء المحرك لك لنفس الأبعاد.
\end{abstract}

Keywords: Switched DC motor, Permanent magnet motor, Brushless DC motor, Torque ripple minimization, Advanced excitation

\section{INTRODUCTION}

Conventional DC machines are highly efficient and their characteristics make them suitable for use as servo motors [1]. Main drawback is that they need a commutator and brushes which are subjected to wear and maintenance. When functions of commutator and brushes are implemented by solid state switches, maintenance-free motors are realized. These machines are called brushless DC machines because their operating characteristics can be made to resemble those of a DC shunt motor with constant field current.

Brushless DC (BLDC) motors are potentially cleaner, faster, more efficient, less noisy, more reliable, and low maintenance. The acceptance of permanentmagnet machines in a variety of applications was inhibited by concerning about cost, reliability and number of connections between machine and controller.

A brushless motor is often used when high reliability, long life and high speeds are required. The bearings in brushes motor usually become the only parts to wear out brushless motor is considered a better choice. With the development of high energy and high temperature resistant permanent magnets, the use of brushless DC motors is gaining momentum in automotive and computer application; they for example rotate normal PC fans, hard disks and disk drives.

BLDC motors can potentially be employed in any field-application currently fulfilled by brushed DC motors [2]. Cost prevents BLDC motors from replacing brushed motors in most common areas of use. Nevertheless, BLDC motors have come to dominate many applications: Consumer devices such as computer hard drives, CD/DVD players, and PC cooling fans use BLDC motors almost exclusively. Low speed, low power brushless DC motor are used in direct- drive turntables. These motors are essentially AC synchronous motors with permanent magnet rotors.

BLDC motors are considered more efficient than brushed DC-motors [3]. This means for the same input power, a BLDC motor will convert more electrical power into mechanical power. The enhanced efficiency is greatest in the no-load and low-load region of the motors performance curve. The characteristics of brushless DC motors are most 
A. M. AL-Khatib, W. Sh. Abou-Alfadl, F. A. Abdel-kader, E. M. Badr, "Theoretical Analysis of Developed ..."

advantageous to the blow molding process as follow:-

1- Very precise average speed control over a very wide speed range.

2- Precise instantaneous speed control due to high dynamic response.

3- Constant power factor means lowest possible input current.

4- Small physical size of motor compared to brush type.

5- No recurring motor maintenance (brush replacement)

6- Feedback device (encoder) is inside the motor not outside

7- Higher efficiency over all

\section{CONSTRUCTION AND EQUIVALENT CIRCUIT}

A brushless DC motor is 3 phase cylindrical stator windings and a salient pole with 2 permanent magnet rotor as shown in Fig. 1, while its equivalent circuit is shown in Fig. 2.

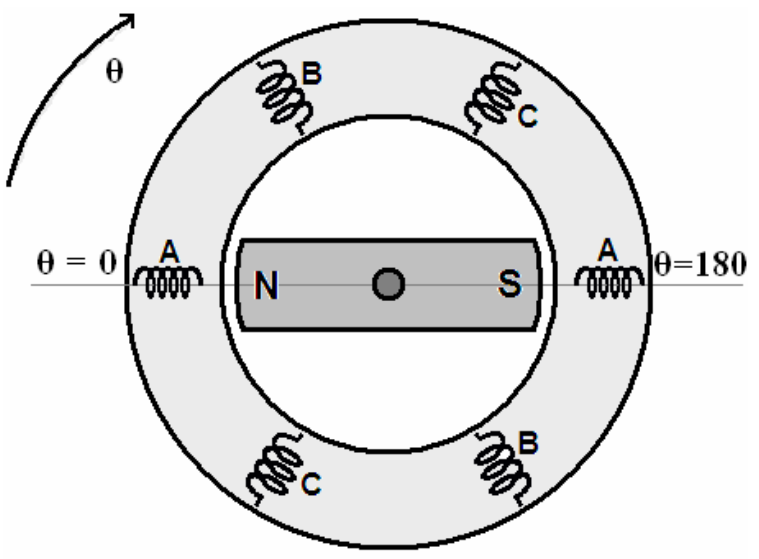

Fig. 1. A simplified diagram of 3 phase PM brushless DC motor

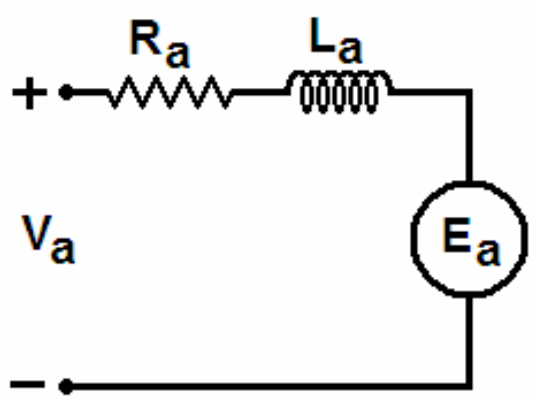

Fig. 2. Phase A equivalent circuit

\section{THE MOTOR VOLTAGE EQUATIONS AND DRIVING CIRCUIT}

The phase voltage equations [4] can be written as;

$\mathrm{V}_{\mathrm{a}}=\mathrm{RI}_{\mathrm{a}}+\mathrm{L}_{\mathrm{a}} \frac{\mathrm{dI} \mathrm{a}}{\mathrm{dt}}+\mathrm{E}_{\mathrm{a}}$

$\mathrm{V}_{\mathrm{b}}=\mathrm{RI}_{\mathrm{b}}+\mathrm{L}_{\mathrm{b}} \frac{\mathrm{dlb}}{\mathrm{dt}}+\mathrm{E}_{\mathrm{b}}$

$\mathrm{V}_{\mathrm{c}}=\mathrm{RI}_{\mathrm{c}}+\mathrm{L}_{\mathrm{c}} \frac{\mathrm{dIc}}{\mathrm{dt}}+\mathrm{E}_{\mathrm{c}}$

where

$\mathrm{V}_{\mathrm{a}}, \mathrm{V}_{\mathrm{b}}$ and $\mathrm{V}_{\mathrm{c}}$ : phases input voltages.

$\mathrm{L}_{\mathrm{a}}, \mathrm{L}_{\mathrm{b}}$ and $\mathrm{L}_{\mathrm{c}}$ : phases inductances.

$\mathrm{E}_{\mathrm{a}}, \mathrm{E}_{\mathrm{b}}$ and $\mathrm{E}_{\mathrm{c}}$ : phases rotational emfs.

$I_{a}, I_{b}$ and $I_{c} \quad$ : phases currents.

$\mathrm{R}$ : phase resistance.

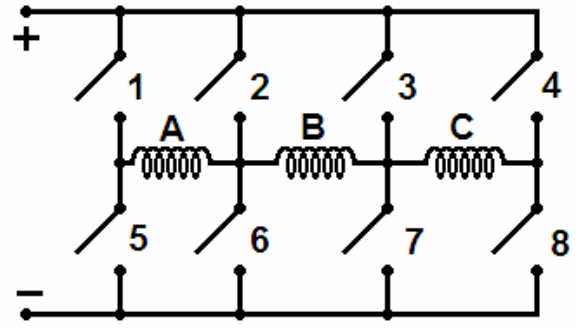

Fig. 3. Driving circuit of the motor

When the rotor rotates from $\theta=0$ to 180 the rotor rotate at some direction and to continue the rotation (from $\theta=180^{\circ}$ to $360^{\circ}$ ), the first winding needs to be excited but with a negative current to make rotate in the same direction sequence of winding excitation as shown in table 1.

Table 1, sequence of winding excitation

\begin{tabular}{|c|c|c|c|c|c|c|}
\hline Steps & 1 & 2 & 3 & 4 & 5 & 6 \\
\hline 1 & 1 & 0 & 0 & 0 & 0 & 0 \\
\hline 2 & 0 & 1 & 0 & 1 & 0 & 0 \\
\hline 3 & 0 & 0 & 1 & 0 & 1 & 0 \\
\hline 4 & 0 & 0 & 0 & 0 & 0 & 1 \\
\hline 5 & 0 & 0 & 0 & 1 & 0 & 0 \\
\hline 6 & 1 & 0 & 0 & 0 & 1 & 0 \\
\hline 7 & 0 & 1 & 0 & 0 & 0 & 1 \\
\hline 8 & 0 & 0 & 1 & 0 & 0 & 0 \\
\hline
\end{tabular}

\section{THEORETICAL ANALYSIS}

\subsection{Motor Instantaneous Characteristics}

The wave form of e.m.f refers to the shape of permanent-magnet and its place in the rotor (at the outer surface or in the deep). The e.m.f of phase A $\left(E_{a}\right)$ takes a trapezoidal shape as given in Fig. 4 and can be calculated as: 
A. M. AL-Khatib, W. Sh. Abou-Alfadl, F. A. Abdel-kader, E. M. Badr, "Theoretical Analysis of Developed ..."

$\mathrm{Ea}=\mathrm{K} \theta$ (at $\theta=0$ to $30 \circ$ )

$\mathrm{E}_{\mathrm{a}}=\mathrm{E}_{\text {max }}\left(\right.$ at $\theta=30$ to $\left.150^{\circ}\right)$

$\mathrm{E}_{\mathrm{a}}=\mathrm{E}_{\text {max }}-(\mathrm{k} \theta-150)\left(\right.$ at, $\theta=150$ to $\left.180^{\circ}\right)$

$\mathrm{E}_{\mathrm{a}}=-\mathrm{K}(\theta-180) \quad\left(\right.$ at $\theta=180^{\circ}$ to $\left.210^{\circ}\right)$

$\mathrm{E}_{\mathrm{a}}=-\mathrm{E}_{\max }\left(\right.$ at $\theta=210^{\circ}$ to $\left.330^{\circ}\right)$

$\mathrm{E}_{\mathrm{a}}=-\mathrm{E}_{\max }+(\mathrm{k}(\theta-330))\left(\right.$ at $\theta=330^{\circ}$ to $\left.360^{\circ}\right)$

where

$\mathrm{E}_{\max } \quad$ : maximum emf.

K : constant.

$\theta \quad$ : rotor angle.

The instantaneous current of phase $A\left(I_{a i}\right)$ is calculated by:-

$\mathrm{I}_{\mathrm{ai}}=\mathrm{I}_{\mathrm{a} \max }\left(1-\mathrm{e}^{- \text {tia } / \text { ta }}\right)\left(\right.$ at $\theta=30^{\circ}$ to $\left.90^{\circ}\right)$

$\mathrm{I}_{\mathrm{ai}}=\mathrm{I}_{\mathrm{af}}\left(\mathrm{e}^{-\mathrm{tia} / \tau \mathrm{a}}\right) \quad\left(\right.$ at $\theta=90^{\circ}$ to $\left.180^{\circ}\right)$

$\mathrm{I}_{\mathrm{ai}}=-\mathrm{I}_{\mathrm{a} \max }\left(1-\mathrm{e}^{- \text {tia } / \mathrm{a} a}\right)\left(\right.$ at $\theta=210^{\circ}$ to $\left.270^{\circ}\right)$

$\mathrm{I}_{\mathrm{ai}}=\mathrm{I}_{\mathrm{af}}\left(\mathrm{e}^{- \text {tia } / \mathrm{\tau a}}\right)\left(\right.$ at $\theta=270^{\circ}$ to $\left.360^{\circ}\right)$

where

$t_{\text {ia }} \quad$ : phase A increasing current time

$\tau_{\mathrm{a}} \quad$ : phase A time constant

$\mathrm{I}_{\mathrm{af}} \quad$ : phase A initial decaying current

$\mathrm{I}_{\mathrm{a} \max }$ : phase A maximum current.

$\mathrm{I}_{\mathrm{a} \max }=\left(\mathrm{V}-\mathrm{E}_{\max }\right) / \mathrm{R}$

$\mathrm{I}_{\mathrm{af}}=\mathrm{I}_{\mathrm{a} \max }\left(1-\mathrm{e}^{-\mathrm{tia} / \tau \mathrm{a}}\right) \quad\left(\right.$ at $\left.\theta=90^{\circ}\right)$

Phase A instantaneous reluctance torque $\left(\mathrm{T}_{\text {ari }}\right)$ is calculated by;

$\mathrm{T}_{\text {ari }}=0.5 \mathrm{I}_{\mathrm{ai}}^{2} \mathrm{~d} \mathrm{~L} \mathrm{~L}_{\mathrm{a}} / \mathrm{d} \theta$

phase A instantaneous permanent magnet torque $\left(\mathrm{T}_{\text {apmi }}\right)$ is

$\mathrm{T}_{\mathrm{apmi}}=\left(\left(\mathrm{E}_{\mathrm{a}} \mathrm{I}_{\mathrm{ai}}\right) / \mathrm{w}\right) \cos (\theta)$

The instantaneous total torque of phase $\mathrm{A}\left(\mathrm{T}_{\mathrm{ati}}\right)$ is

$\mathrm{T}_{\mathrm{ati}}=\mathrm{T}_{\text {ari }}+\mathrm{T}_{\mathrm{apmi}}$

The instantaneous input power of phase $\mathrm{A}\left(\mathrm{P}_{\text {inai }}\right)$ is

$\mathrm{P}_{\text {ina }}=\mathrm{VI}_{\mathrm{a}}$

The previous equations calculate e.m.f wave, current, torque and input power of phase $\mathrm{A}$. Those equations can be used for phases $\mathrm{B}$ and $\mathrm{C}$ by shifting their space angles with 60 and 120degree respectively.

Also phase $\mathrm{C}$ shifted by phase $\mathrm{B}$ by 60 degree on the space. Figures (4-5) show Motor phases e.m.f, and Motor phases currents.

The instantaneous motor total torque $\left(\mathrm{T}_{\text {moti }}\right)$ is

$\mathrm{T}_{\text {moti }}=\mathrm{T}_{\mathrm{ati}}+\mathrm{T}_{\mathrm{bti}}+\mathrm{T}_{\mathrm{cti}}$

The instantaneous output power $\left(\mathrm{P}_{\mathrm{oi}}\right)$ is

$\mathrm{P}_{\mathrm{oi}}=\mathrm{T}_{\text {moti }} \mathrm{W}$

The instantaneous input power $\left(\mathrm{P}_{\text {int }}\right)$ is then

$\mathrm{P}_{\text {inti }}=\mathrm{P}_{\text {inai }}+\mathrm{P}_{\text {inbi }}+\mathrm{P}_{\text {inci }}$

The system instantaneous efficiency $\left(\mathrm{E}_{\mathrm{ff}}\right)$ is then

$\mathrm{E}_{\mathrm{ffi}}=\mathrm{Po}_{\mathrm{i}} / \mathrm{P}_{\text {inti }}$

\subsection{Motor Average Characteristics}

The average phase current is

$$
\begin{gathered}
\theta=180 \\
\mathrm{I}_{\mathrm{av}}=(1 / 180) \sum_{\mathrm{ai}} \\
\theta=0\left(\operatorname{step}=1^{\circ}\right)
\end{gathered}
$$

The motor average torque is

$$
\begin{gathered}
\theta=180 \\
\mathrm{~T}_{\text {motv }}=(1 / 180) \sum \mathrm{T}_{\text {moti }} \\
\theta=0\left(\text { step }=1^{\circ}\right)
\end{gathered}
$$

The average output power is

$$
\begin{gathered}
\theta=180 \\
\mathrm{P}_{\mathrm{ov}}=(1 / 180) \sum \mathrm{P}_{\mathrm{oi}} \\
\theta=0\left(\text { step }=1^{\circ}\right)
\end{gathered}
$$

The input average power is then

$$
\begin{gathered}
\theta=180 \\
\mathrm{P}_{\text {inv }}=(1 / 180) \sum_{\text {ini }} \\
\theta=0\left(\text { step }=1^{\circ}\right)
\end{gathered}
$$

The system average efficiency may be

$$
\begin{gathered}
\theta=180 \\
\mathrm{E}_{\mathrm{ffv}}=(1 / 180) \sum \mathrm{E}_{\mathrm{ffi}} \\
\theta=0\left(\text { step }=1^{\circ}\right)
\end{gathered}
$$

The torque ripple (TRR ) calculate

$$
\theta=180
$$

$\left.\mathrm{TRR}=\sum \operatorname{Abs}\left(\mathrm{T}_{\text {mot }}-\mathrm{T}_{\text {motv }}\right) / \mathrm{T}_{\text {motv }}\right)$ $\theta=0$

number of steps from $\theta=0 \longrightarrow 180^{\circ}$

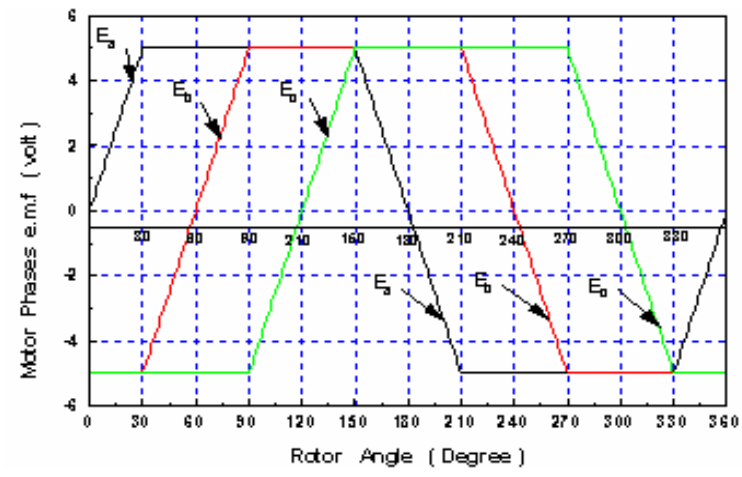

Fig. 4. Motor phases e.m.f

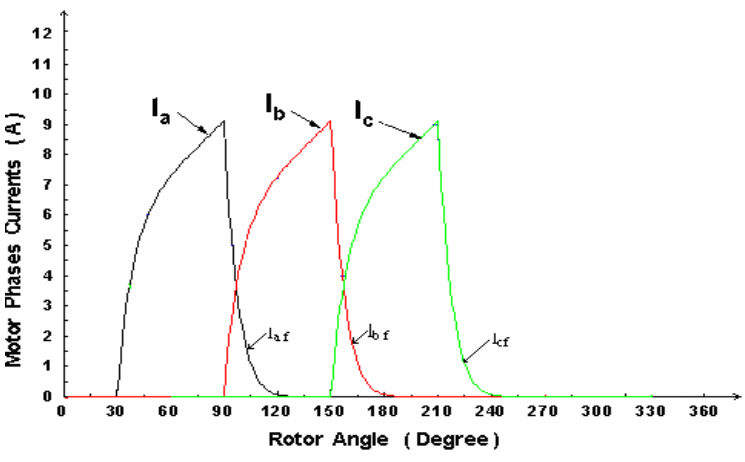

Fig. 5. Motor phases currents 
A. M. AL-Khatib, W. Sh. Abou-Alfadl, F. A. Abdel-kader, E. M. Badr, "Theoretical Analysis of Developed ..."

\section{FACTORS AFFECTING THE OPERATION OF THE MOTOR}

\subsection{Instantaneous motor Characteristics}

Performance Characteristics of the motor are affected by changing the values of applied voltage, motor speed and permanent magnet flux density as presented in Figures (6-11). These figures show that motor current and torque increase by increasing voltage and decrease by increasing the speed. Increasing permanent magnet flux density leads to motor phases current decrease while the motor total torque increase

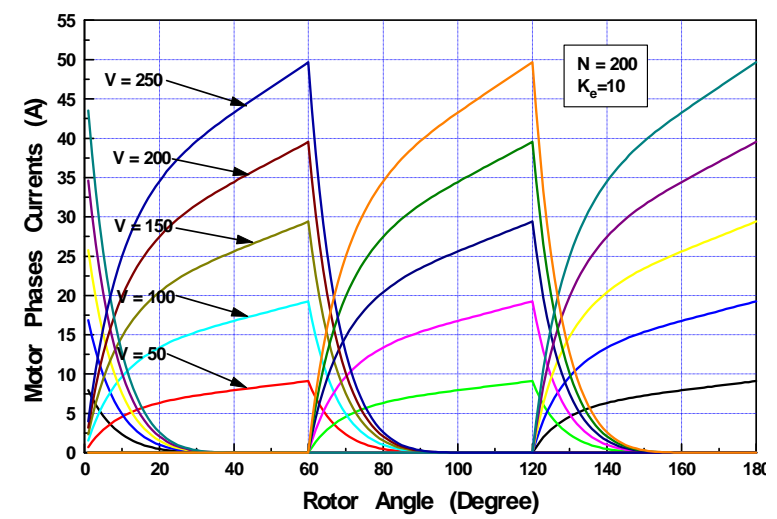

Fig. 6. Variation of motor phases currents at different values of motor applied voltage

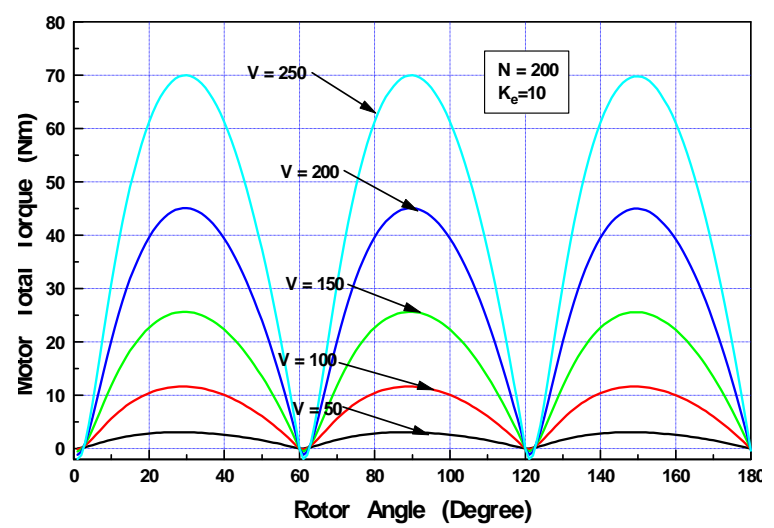

Fig. 7. Variation of motor total torque at different values of motor applied voltage

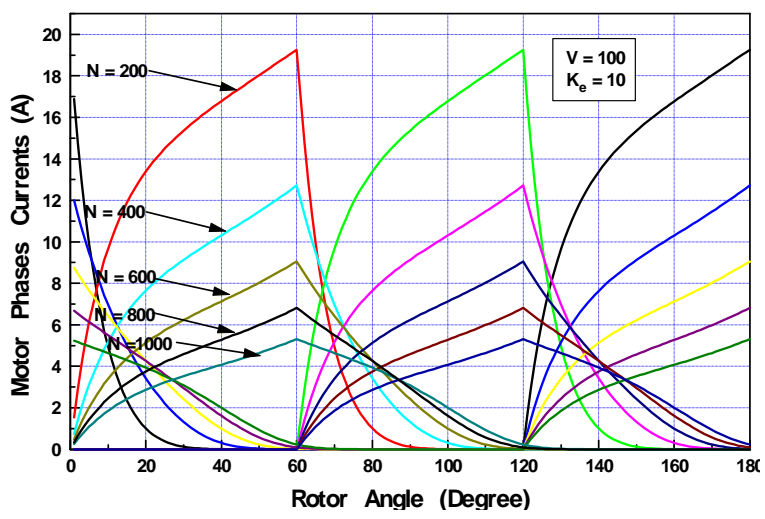

Fig. 8. Variation of motor phases currents at different values of motor speed

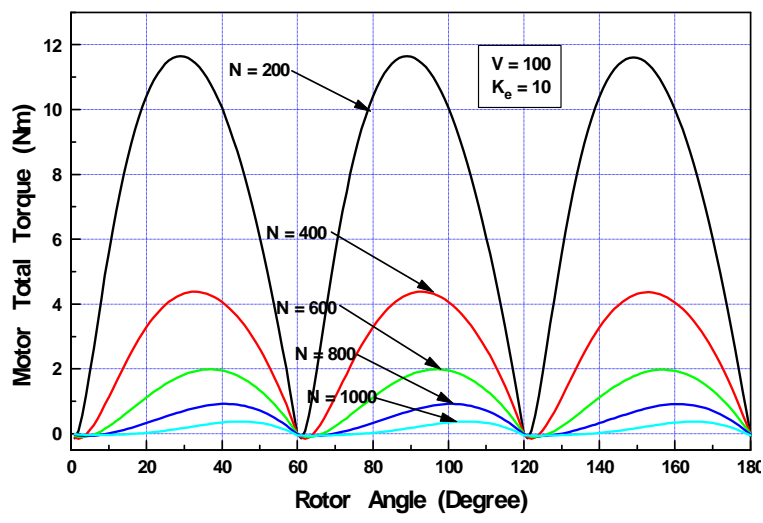

Fig. 9. Variation of motor total torque at different values of motor speed

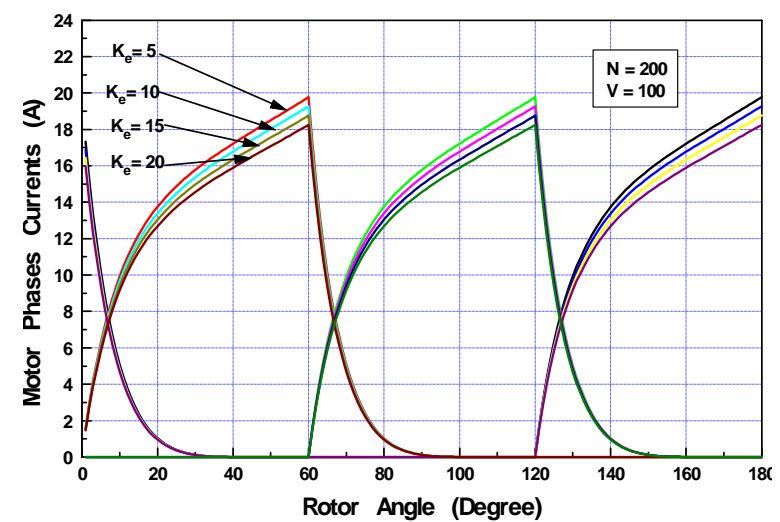

Fig. 10. Variation of motor phases currents at different values of permanent magnet flux density

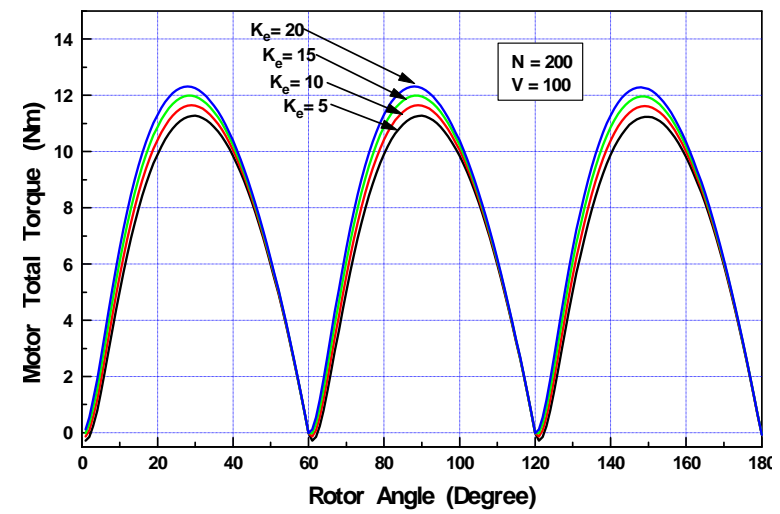

Fig. 11. Variation of motor total torque at different values of permanent magnet flux density

\subsection{Average motor Characteristics}

Motor average performance characteristics presented in Figs.(12-15).The figures show that motor current increases by increasing voltage but decreases by increasing permanent magnet flux density. The motor torque increases by increasing voltage and permanent magnet flux density. 
A. M. AL-Khatib, W. Sh. Abou-Alfadl, F. A. Abdel-kader, E. M. Badr, "Theoretical Analysis of Developed ..."

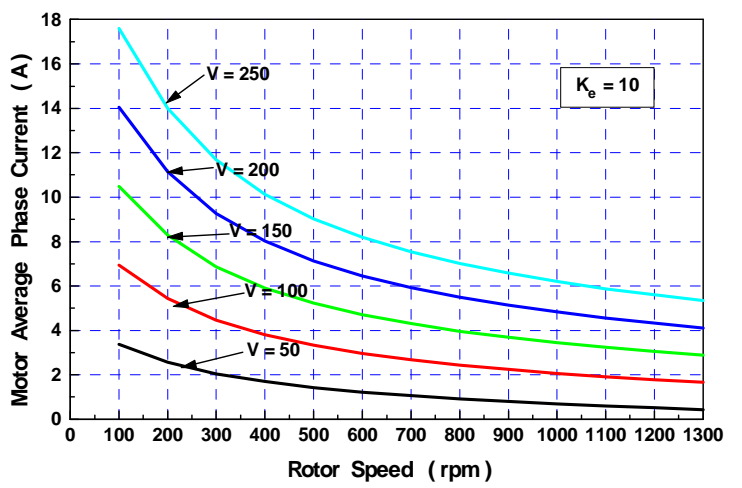

Fig. 12. Variation of motor average current at different values of applied voltage

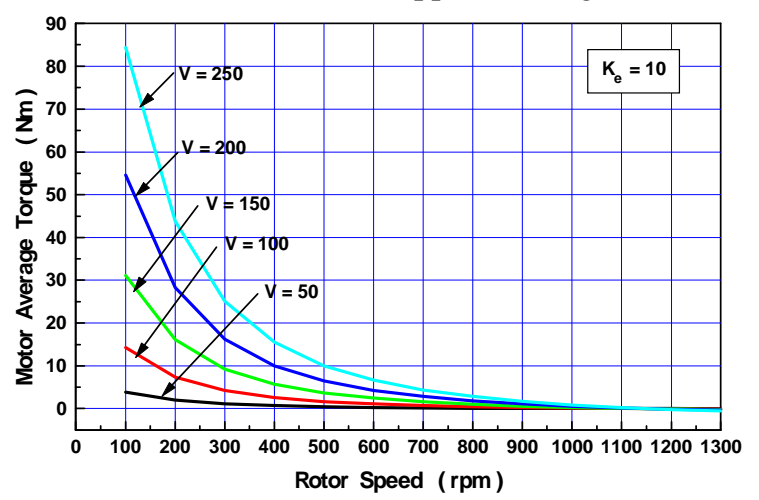

Fig. 13. Variation of motor average torque at different values of applied voltage

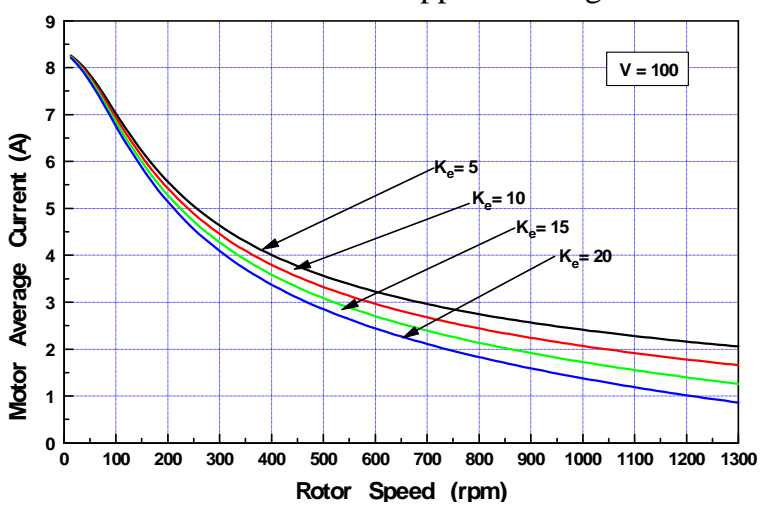

Fig. 14. Variation of motor average current at different values of permanent magnet flux density

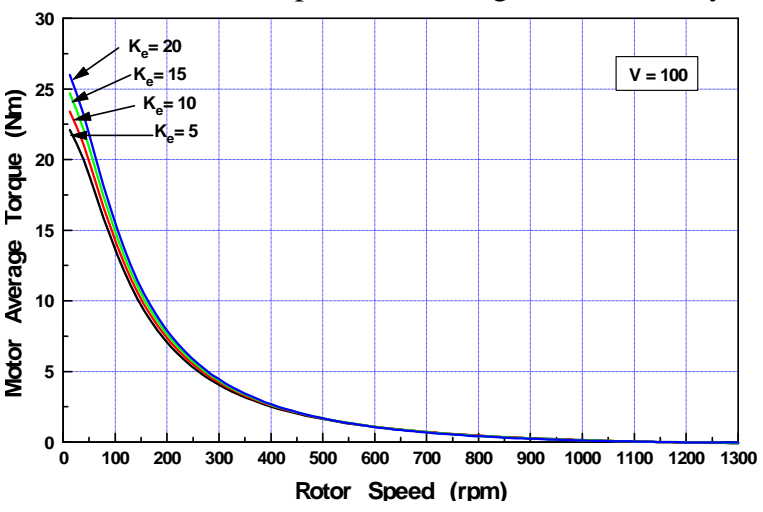

Fig. 15. Variation of motor average torque at different values of applied voltage

\section{EFFECT OF PHASE ADVANCED ON THE OPERATION OF THE MOTOR}

Phase advancing angle has a great effect on the instantaneous and average motor characteristics. As increasing the value of phase advancing angle, all motor characteristics increase as shown in Figs (1621 ) and the torque wave form is improved. The value of efficiency increases by increasing phase advancing angle.

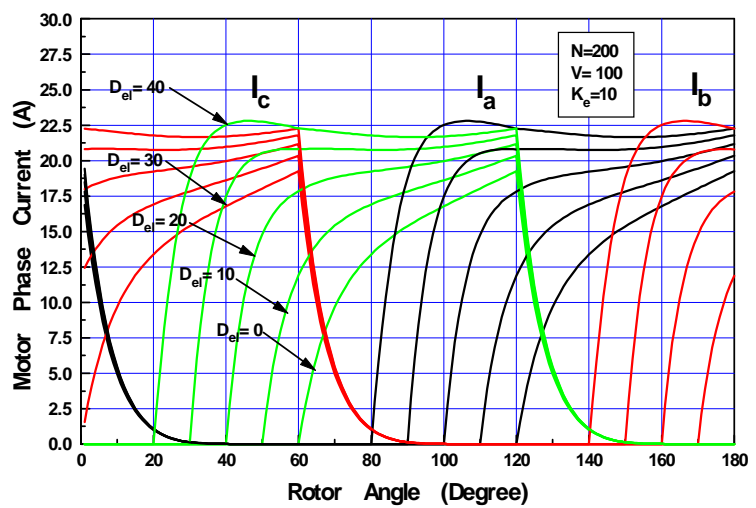

Fig. 16. Variation of motor phases currents at different values of delta

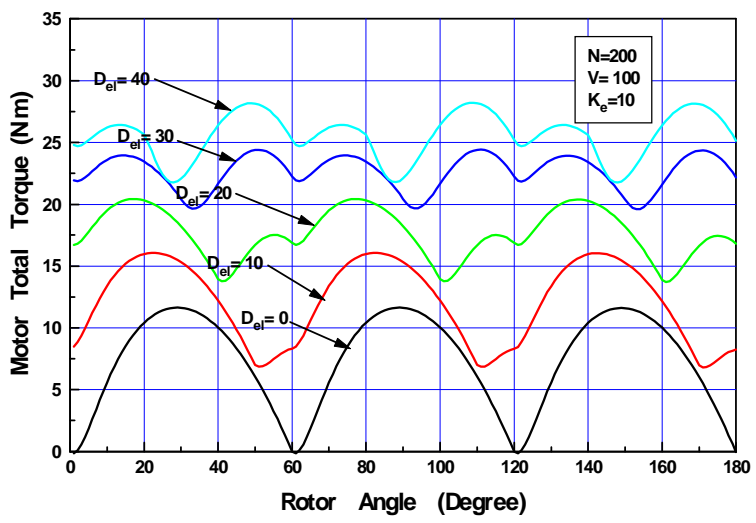

Fig. 17. Variation of motor total torque at different values of delta

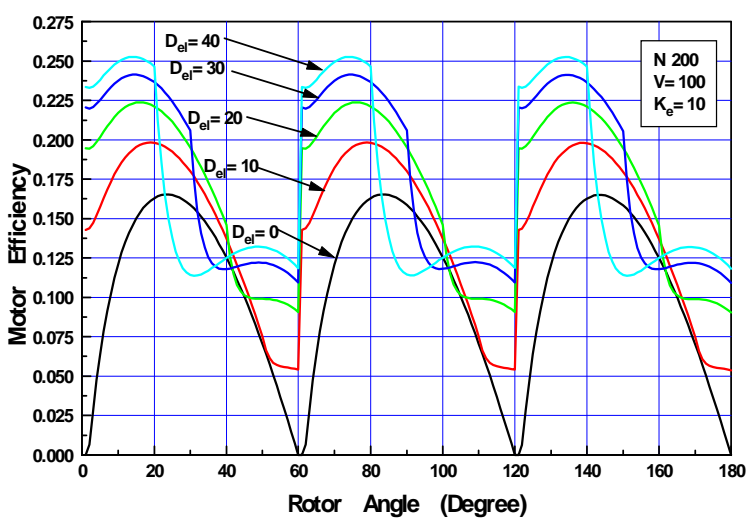

Fig. 18. Variation of motor efficiency at different values of delta 


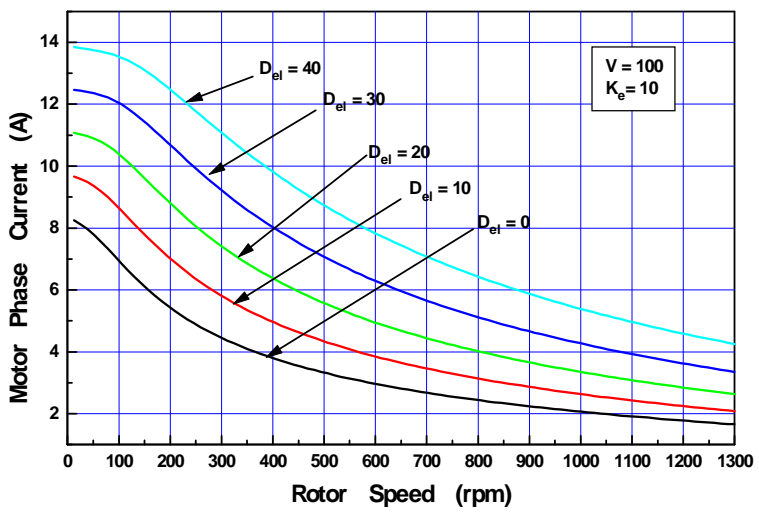

Fig. 19. Variation of motor average current at different values of delta

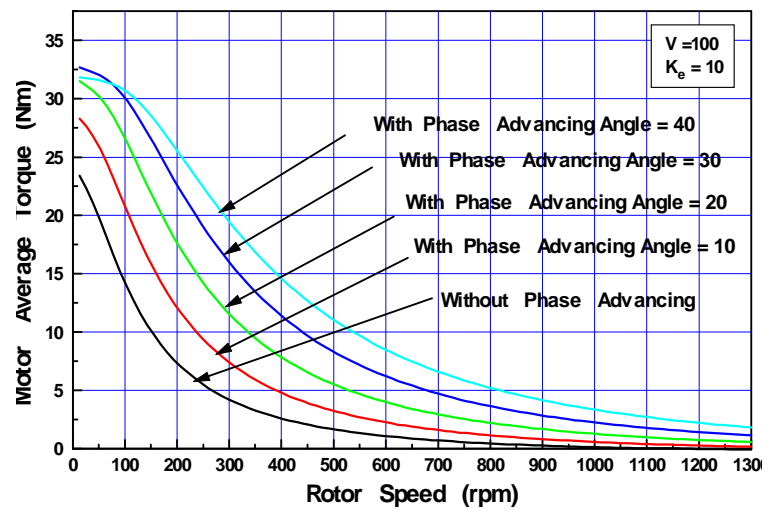

Fig. 20. Variation of motor average torque at different values of delta

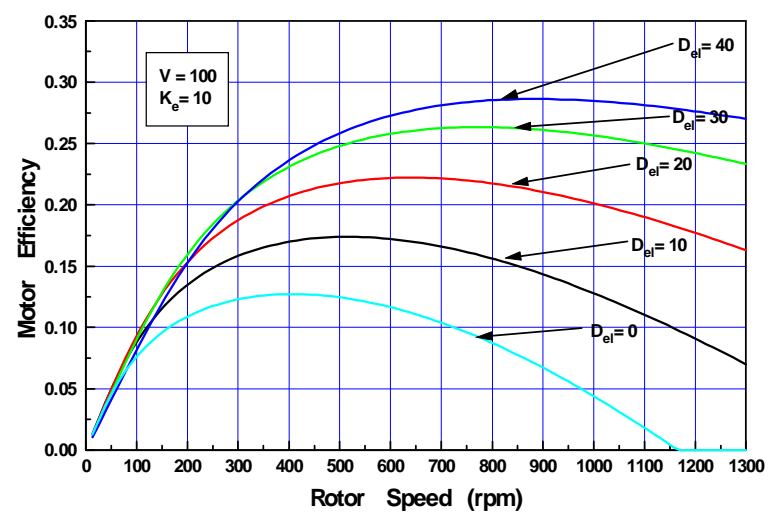

Fig. 21. Variation of motor efficiency at different values of delta

\section{EFFECT OF PHASE ADVANCED ON THE TORQUE RIPPLE OF THE MOTOR}

By increasing phase advancing angle, motor torque ripple decreases and the torque wave form improves. Figure 22, shows the effect of increasing phase advancing angle on the value of motor torque ripple.

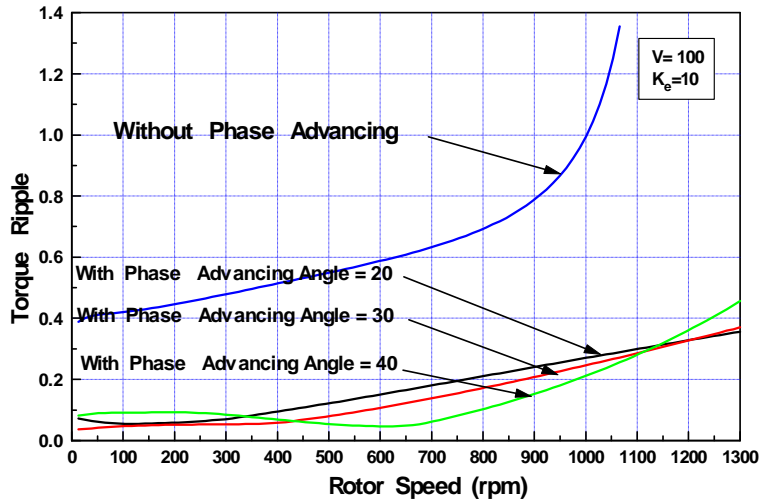

Fig. 22. Variation of torque ripple at different values of delta

\section{CONCLUSION}

A comparative study is carried out on a real BLDC motor, for conventional and proposed excitation methods. The important results are given in details at different excitation voltage, permanent magnet constant, rotor speed and advancing angle (time).By increasing voltage and permanent magnet constant motor current and torque peak values increase but decrease by increasing motor speed. Increasing phase advancing angle maximizes motor characteristics and increasing output torque with minimum ripple factor. As example, at $200 \mathrm{rpm}, 100 \mathrm{~V}, 10 \mathrm{pm}$ constant the starting torque ratio is $(32 / 24)$. The lead torque ratio $(25 / 7)$ and the ripple factor ratio is $(0.1 / 0.425)$.In general the ripple factor at low speed $(0-700 \mathrm{rpm})$ is less than 0.1 , but in the conventional method is greater than 0.4 and increasing with increasing the motor speed but at high speed (700-1200 rpm)the ripple factor increase linearly and don't reach 0.3 ripple factor, while in conventional method is increased as function of speed square.

\section{REFERENCES}

[1] A.Lelkes and M.Bufe, "BLDC Motor for Fan Application with Automatically Optimized Commutation Angle",VS-Villingen,Germany, IEEE,September,2009.

[2] K.S.Rama Rao,Nagadeven and Soib Taib, "Sensorless Control of a BLDC Motor with Back EMF Detection Method Using DSPIC", IEEE, September,2009, PP.1- 5.

[3] Jianwen shao, "An Improved Microcontrollerbased Sensorless Brushless DC (BLDC) Motor Drive for Automotive Applications" IEEE, September,2009, PP.1- 6 .

[4] Padmarjayedmale, "Brushless DC (BLDC) motor fundamentals", Microship technology lnc,AN 885,Ds 00885A,2003, PP.1- 6 